\title{
Characteristics of pathogens which might be used in an bioterrorism attack
}

\section{Charakterystyka patogenów mogących mieć zastosowanie w ataku bioterrorystycznym}

\author{
Piotr Daniszewski \\ Faculty of Biology, University of Szczecin, \\ 13 Waska Street, 71-415 Szczecin, Poland \\ E-mail address: daniszewski73@gmail.com
}

\begin{abstract}
Bioterrorism is a complex and dynamic phenomenon, occurring in various forms. It is difficult now to define a uniform definition of terrorism that is changing under the influence of the development of civilization, and especially the rapid progress in scientific and technical knowledge. The terrorists perfectly use the latest achievements of biological sciences in their terrorist attacks. The purpose of this article is to bring the phenomenon of bioterrorism.
\end{abstract}

Keywords: terrorism; bioterrorism; the threat; security; terrorist attack

\section{STRESZCZENIE}

Bioterroryzm to zjawisko wielopłaszczyznowym i dynamicznym, występujące w różnych postaciach. Trudno jest obecnie zdefiniowanie jednolitej definicji terroryzmu, który zmienia się pod wpływem rozwoju cywilizacyjnego, a zwłaszcza szybkiego postępu naukowo-technicznego. Terroryści perfekcyjnie wykorzystują najnowsze zdobycze nauk biologicznych w swoich atakach terrorystycznych. Celem artykułu jest przybliżenie zjawiska bioterroryzmu.

Slowa kluczowe: terroryzm, bioterroryzm, zagrożenie, bezpieczeństwo, atak terrorystyczny.

\section{WPROWADZENIE}

Broń masowego rażenia (inaczej broń masowej zagłady, broń $\mathrm{ABC}$ ): ,jest to broń o niekonwencjonalnym ładunku rażącym:

A - atomowym, B - biologicznym, C - chemicznym,

o wielkiej sile rażenia, co do której użycia obowiązuje bezwzględny zakaz (jej użycie jest sprzeczne $\mathrm{z}$ normami prawa międzynarodowego)" [1-8,10,11]. Brak jest obecnie 
jednoznacznego zdefiniowania pojęcia terroryzmu. Powodem tego stanu jest brak możliwości stworzenia definicji, która akceptowana byłaby przez społeczeństwo międzynarodowe, a co za tym idzie objąć zagadnienia terroryzmu jednolitym aktem prawnym na forum międzynarodowym [1-8,10,11,19,25-28].

\section{NAJWAŻNIEJSZE PATOGENY MOGĄCE MIEĆ ZASTOSOWANIE W ATAKU BIOTERRORYSTYCZNYM}

1. wirusy: ospy prawdziwej, gorączki krwotocznej oraz zapalenia mózgu,

2. bakterie: Bacillus anthracis (wąglik), Brucella sp. (bruceloza), Coxiella burnetti (gorączka Q), Francisella tularensis (tularemia) i Yersinia pestis (dżuma),

3 . toksyny: gronkowcowa enterotoksyna $\mathrm{B}$, rycyna, toksyna botulinowa $[1,8,10,11,25$ 32].

\section{1. Wąglik (Bacillus anthracis) jako czynnik zakaźny zastosowany w ataku bioterrorystycznym}

\section{- Stan epidemiologiczny}

Choroba odzwierzęca rozpowszechniona na całym świecie, ok. 2000 przypadków rocznie (ponad $90 \%$ to postać skórna). W XIX w. pojawiała się w postaci płucnej (strzyżenie chorych owiec i przeróbka wełny). Nie szerzy się epidemicznie wśród ludzi, zwierzęta zakażają się przetrwalnikami z gleby. W Polsce sporadyczne przypadki (choroba zawodowa) [1-8,10,11].

\section{- Patogeneza i główne postacie}

- przetrwalniki bakterii są fagocytowane przez makrofagi, gdzie są uwalniane bakterie, które wytwarzają egzotoksynę obrzękową (hamuje cyklazę adenylową) i egzotoksynę martwiczą (powoduje cytolizę makrofagow),

- występuje w 3 postaciach:

- postać skórna (czarna krosta),

- postać płucna,

- postać jelitowa (pokarmowa, trzewna) [1-5,10,11,17,23-27].

- Wąglik jako broń biologiczna

\section{1. 1. Objawy kliniczne zakażenia wąglikiem}

\section{Postać plucna:}

- gorączka, kaszel, bole w klatce piersiowej, duszność, sinica, wstrząs,

- charakterystyczne objawy zapowiadające zespół grypopodobnego trwające 2-4 dni,

- możliwość przejściowej poprawy,

- wystąpienie objawów ostrej niewydolności oddechowej i niewydolności krążenia z poszerzeniem śródpiersia na zdjęciu rentgenowskim płuc,

- pojawienie się Gram dodatnich bakterii w posiewie krwi po 2-3 dniach trwania choroby,

- śmierć po upływie 24-36 h wśród pogłębiających się objawów,

- krwotoczne zapalenie opon mózgowo-rdzeniowych w 50 \% przypadków.

Możliwość wyleczenia postaci płucnej wąglika jest największa w okresie prodromalnym (cyprofloksacyna, doksycyklina). Leczenie wdrożone w okresie późniejszym rzadko jest skuteczne [1-8,10,11,18,24-31]. 


\section{Postać jelitowa:}

- ból brzucha, nudności, wymioty i gorączka po zjedzeniu zakażonego pokarmu (w sytuacji nie związanej z atakiem bioterrorystycznym najczęściej po spożyciu mięsa),

- krwawa biegunka, krwawe wymioty,

- posocznica i toksemia prowadzące do wstrząsu i zgonu [1-8,10,11,18,24-31].

\section{1. 2. Czas ujawnienia się zakażenia}

- postać płucna wąglika może pojawić się średnio po 5 dniach, po okresie utajenia trwającym od 2 do 60 dni,

- postać jelitowa pojawia się po 1-7 dniach od momentu zakażenia,

- postać skórna pojawia się po 1-7 dniach od momentu zakażenia [1-8,10,11,18,24-31].

\section{1. 3. Działania zapobiegawcze}

Szczepionki przeciw wąglikowi są trudno dostępne i obecnie nie są zalecane ludności cywilnej [1-8,10,11,18,22-30]. Najskuteczniejszym środkiem leczniczym jest surowica przeciw wąglikowa. Profilaktyczną antybiotykoterapię stosuje się wyłącznie na zlecenie lekarza u osób narażonych na zakażenie ze wspólnego źródła z potwierdzonymi przypadkami klinicznymi. U dzieci w profilaktyce powinna być stosowana amoksycylina [1-8,18,24-31].

\section{1. 4. Nadzór epidemiologiczny nad osobami chorymi}

- obowiązek przymusowej hospitalizacji,

- brak konieczności izolacji ani osobnych pokoi w szpitalu,

- transport pacjentów chorych na wąglik nie wymaga szczególnych zabezpieczeń,

- w postaci skórnej wąglika możliwe jest zakażenie w wyniku kontaktu bezpośredniego $[1-8,10,11,18,24-31]$.

\section{2. Jad kiełbasiany (egzotoksyna botulinowa, botulinismus) jako czynnik mogący mieć zastosowanie w ataku bioterrorystycznym}

\section{2. 1. Charakterystyka patogenu}

Jad kiełbasiany jest silną neurotoksyną produkowaną przez Gram-dodatnią bakterię Clostridium botuli-num w warunkach beztlenowych. Przypadkowe zatrucia jadem kiełbasianym występują po spożyciu za-każonych i niewłaściwie przechowywanych potraw konserwowanych (najczęściej konserwy mięsne, rybne i warzywne) [1-8,10,11,18,24-31].

\section{2. 2. Mechanizm działania}

Blokowanie połączeń nerwowo-mięśniowych (neurotransmisji). Toksyna botulinowa, jako broń biologiczna:

- mała dawka śmiertelna: 0,09-0,15 $\mu \mathrm{g}$ domięśniowo, 0,70-0,90 $\mu \mathrm{g}$ wziewnie i 70,00 $\mu \mathrm{g}$ doustnie,

- duże ilości stabilizowanej botuliny dostępnej na „rynku”

- stosunkowo łatwy sposób ataku (aerozol, zanieczyszczenie żywności),

- szybki efekt toksyczny (od kilku godzin do kilku dni),

- dość charakterystyczne objawy [1-8,10,11,18,24-31]. 


\section{2. 3. Sygnały zagrożenia}

1. jednoczesne lub w krótkich odstępach czasu wystąpienie potwierdzonych klinicznie i/lub laboratoryjnie zatruć jadem kiełbasianym w ilości przekraczającej średnią z ostatnich trzech miesięcy,

2. jednoczesne lub w krótkich odstępach czasu wystąpienie zespołów klinicznych (nie potwierdzonych etiologicznie) objawami przypominających zatrucie jadem kiełbasianym,

3. dokonany atak bioterrorystyczny z użyciem jadu kiełbasianego w innych krajach, szczególnie ościennych,

4. groźba (jawna lub pochodząca $z$ danych wywiadu) ze strony organizacji ekstremistycznych (w tym państw) dokonania ataku bioterrorystycznego z użyciem jadu kiełbasianego [1-8,10,11,18,24-31].

\section{2. 4. Źródła zatrucia jadem kiełbasianym w ataku bioterrorystycznym}

- pokarmy zatrute jadem kiełbasianym,

- wdychany aerozol zawierający toksynę botulinową [1-8,10,11,18,24-31].

\section{2. 5. Okres wylęgania}

- po spożyciu pokarmów zatrutych jadem kiełbasianym objawy neurologiczne pojawiają się wcześniej (12-36 h),

- po kontakcie drogą wziewną objawy neurologiczne pojawiają się później (po 24-72 h) [1-8,10,11,18,24-31].

Brak jest szczepionki przeciw jadowi kiełbasianemu. Natomiast dostępna jest szczepionka przeciwtoksynowa (profilaktycznie) oraz immunoglobulina (leczniczo) [18,18,24-31].

\section{2. 6. Nadzór epidemiologiczny nad osobami chorymi}

- osoby, u których stwierdzono lub podejrzewa się zatrucie jadem kiełbasianym, podlegają przymusowej hospitalizacji,

- wymagane stosowanie uniwersalnych środków bezpieczeństwa biologicznego na poziomie BSL-2,

- chorzy nie wymagają izolacji ani osobnych pokoi w szpitalu,

- transport chorych nie wymaga szczególnych zabezpieczeń,

- brak dodatkowych zaleceń epidemiologiczno-sanitarnych po wypisaniu ze szpitala $[1-8,10,11,18,24-31]$.

\section{3. Zagrożenia wynikające $z$ zakażenia tularemią}

\subsection{Charakterystyka patogenu}

W 1911 roku wśród wiewiórek w Tulare County (Kalifornia) zaobserwowano podobną do dżumy zoonozę. Od chorych zwierząt McCoy i Chapin wyizolowali drobną Gram-ujemną pałeczkę, którą nazwali Bacterium tularensis. Edward Francis opisał jej ekologię. Na jego cześć bakterię przemianowano na - Francisella tularensis. W warunkach naturalnych tularemia występuje prawie wyłącznie w środowisku wiejskim w Ameryce Płn., Azji i Europie [1-5,10,13-17,22,24-31]. Typ A Francisella tularensis występuje w Ameryce Płn., typ B, wywołujący chorobę o łagodniejszym przebiegu, występuje w Ameryce Północnej, 
Europie i Azji. In vitro pałeczka ta rośnie w warunkach tlenowych, jest bezotoczkowa i nie wytwarza zarodników [1-5,10,13-17,22,24-31].

\section{3. 2. Patogeneza}

- objawy chorobowe wywołują składniki otoczki komórki bakteryjnej, bakteria namnaża się wewnątrz makrofagów,

- postać wrzodziejąco-węzłowa (75\%), postać oczno-węzłowa, postać anginowa, postać płucna, postać trzewna [1-5,10,13-17,22,24-31].

\section{3. 3. Postacie kliniczne}

- wrzodowo-gruczołowa,

- wrzód z regionalną adenopatią;

- gruczołowa,

- regionalna adenopatia bez widocznego uszkodzenia skóry;

- oczno-gruczołowa,

- bolesne ropne zapalenie spojówek z adenopatią;

- tyfoidalna,

- posocznica, bez adenopatii;

- możliwy obraz po ataku terrorystycznym;

- płucna (pierwotna lub wtórna),

- możliwy obraz po ataku terrorystycznym [1-5,10,13-17,22,24-31].

\section{3. 4. Objawy i przebieg choroby}

- objawy choroby pojawiają się zazwyczaj w przeciągu 3-5 dni od zakażenia, ale istnieje też możliwość przedłużenia okresu wylęgania nawet do 2-3 tyg.,

- początek choroby jest zwykle nagły, z gorączką 38-40 st. C, bólem głowy, bolami mięśniowymi i bólem gardła; często pojawia się suchy kaszel i ból za mostkiem lub duszność bez typowych objawów zapalenia płuc,

- czasem występuje biegunka, nudności i wymioty,

- w miarę trwania choroby postępuje osłabienie, brak apetytu i utrata masy ciała [1-5,10, 13-17,22,24-31].

\section{3. 5. Francisella tularensis jako broń biologiczna}

- duża zakaźność: 10-50 bakterii wchłoniętych z powietrza stanowi dawkę zakaźną,

- wysoka podatność populacji przy ataku aerozolowym z powietrza (szacowane straty: ok. 100000 poszkodowanych po rozpyleniu $50 \mathrm{~kg}$ zawiesiny nad $0,5 \mathrm{mln}$ miastem),

- nietypowość objawów, trudna diagnostyka mikrobiologiczna [1-5,10,13-17,22,24-31].

\section{4. Zagrożenia wynikające z zakażenia brucelozą}

Bruceloza (gorączka maltaoska, choroba Banga, gorączka falująca, gorączka skalna, gorączka gibraltarska, gorączka Rio-grande) [1-5,10,13-17,22,24-31]. 


\section{4. 1. Brucella abortus}

- bakteria Gram-ujemna,

- patogen fakultatywnie wenątrzkomórkowy,

- gospodarz pierwotny: bydło,

- inni gospodarze: człowiek, bizon, łoś, koza, owca, świnia,

- bruceloza bydła: poronienia [1-5,10,13-17,22,24-31].

\section{4. 2. Brucella suis}

- gospodarz pierwotny: świnia, renifer,

- inni gospodarze: człowiek, bydło, konie, psy,

- bruceloza u świń: poronienia i bezpłodność,

- bruceloza u ludzi: gorączka zwalniająca,

- przenoszenie drogą pokarmową/u zwierząt weneryczną [1-5,10,13-17,22,24-31].

\section{4. 3. Brucella melitensis}

- gospodarz pierwotny: koza, owca,

- inni gospodarze: człowiek, bydło rogate, wielbłąd,

- bruceloza u kóz: poronienia, niepłodność,

- bruceloza u ludzi: gorączka zwalniająca,

- poważny problem zdrowotny i ekonomiczny [1-5,10,13-17,22,24-31].

\section{4. 4. Charakterystyka patogenu}

Bruceloza (gorączka śródziemnomorska, u zwierząt ronienie zakaźne), to choroba zakaźna zwierząt i ludzi występująca $\mathrm{w}$ kilku postaciach, wywoływana przez pałeczki z rodzaju Brucella, odkryte w 1887 na Malcie przez angielskiego lekarza weterynarii D. Bruce'a, który opisał pałeczkę maltaoską (Brucella meli-tensis) powodującą zakaźne ronienie kóz. W 1896 duński lekarz weterynarii B.L.F.Bang odkrył i opisał bakterię, nazwaną od jego nazwiska pałeczką Banga (Brucella abortus var. bovis), wywołującą zakaźne ronienie bydła. Bruceloza należy do najniebezpieczniejszych chorób odzwierzęcych, o nierzadko śmiertelnym przebiegu [1-5,10,13-17,22,24-31].

\section{4. 5. Charakterystyka kliniczna brucelozy}

- układowe zakażenie bakteryjne,

- choroba nabyta najczęściej przez kontakt z zakażonymi zwierzętami i ich mięsem lub rzadziej drogą pokarmową przez spożycie drobnoustrojów w zakażonych produktach zwierzęcych (mleko),

- wnikanie bakterii przez uszkodzoną skórę lub błony śluzowe, u zwierząt także w trakcie krycia,

- okres wylęgania trwa zwykle 5-60 dni, jest jednak rożny i może trwać nawet kilka miesięcy,

- choroba przebiega z przerywaną, nieregularną gorączką i z rożnie nasilonymi objawami klinicznymi - od przypadków skąpo objawowych do zajęcia prawie wszystkich narządów,

- zwykle zajęte są kości i stawy, samców wywołuje zapalenie najądrza i jąder [1-5,10, 13-17,22,24-31]. 


\section{4. 6. Objawy brucelozy}

- gorączka, osłabienie, bole głowy, pocenie się, dreszcze, uogólnione bole, bole stawów (90\%),

- częste są: utrata masy ciała, depresja, męczliwość psychiczna,

- powiększenie wątroby i śledziony (20-30\%),

- cechy uszkodzenia wątroby (nieprawidłowe wyniki badań wątrobowych) - 30-60 \%,

- objawy ze strony przewodu pokarmowego (rzadkie) [1-5,10,13-17,22,24-31].

\section{4. 7. Brucella sp. jako broń biologiczna}

- pierwszy mikroorganizm „uzbrojony” przez USA,

- bomby klasterowe wypełnione B. suis testowano w 1955 r.; program zatrzymano w 1967 r.,

- wszystkie zapasy w USA zniszczono w 1969 r.,

- pewną ilość zagubionej amunicji znaleziono w latach 90-tych ubiegłego wieku i zniszczono,

- 8-10 opiekujących się na jednego chorego,

- choroba przewlekła - długotrwałe leczenie antybiotykami,

- nawroty - objawy psychotyczne,

- niska dawka potrzebna do zakażenia człowieka,

- mikroorganizm z poziomu BL-3,

- łatwo ulegający arezolizacji,

- łatwy do namnożenia,

- łatwo dostępny - powszechny na całym świecie,

- nie ma szczepionki dla ludzi,

- szczepionki ludzkie patogenne dla człowieka,

- odpowiedź humoralna nie daje odporności; niezbędna jest odporność komórkowa,

- rekonwalescencja jest długa, niezależnie od leczenia [1-5,10,13-17,22,24-31].

\section{5. Zagrożenia wynikające $z$ zakażenia dżumą}

\subsection{Charakterystyka patogenu}

W warunkach naturalnych przeniesienie patogenu następuje poprzez pchły, które żerują na gryzoniach żywiąc się ich krwią [1-5,10,13-17,22,24-31]. Ze względu na częstość zmiany żywiciela przez pchły oraz zwracanie przez nie treści pokarmowej, w której zdążyły bakterie się namnożyć, dochodzi do kolejnych zakażeń [1-5,10,13-17,22,24-31]. Człowiek jest gospodarzem przypadkowym.

W "naturalnej" epidemii, zachorowania zwierząt poprzedzają zachorowania u ludzi; w populacji miejskiej pierwszych przypadków dżumy wśród ludzi można oczekiwać, jeśli zarażeniu Yersinia pestis uległo ok. 10 \% szczurów (Rattus norvegicus) [1-5,10,13-17,22,2431]. Epidemie wybuchają $\mathrm{w}$ okresie chłodnym i wilgotnym. Jest to powiązane $\mathrm{z}$ ekologią pchły szczurzej - temp. wyższa niż $28^{\circ} \mathrm{C}$ hamuje rozwój [1-5,10,13-17,22,24-31].

Optymalna temperatura wzrostu bakterii wynosi $28{ }^{\circ} \mathrm{C}$, ale jej tolerancja waha się od 0 do $43{ }^{\circ} \mathrm{C}$. Bakterie rosną dobrze na agarze z krwią, widoczne są jednak dopiero po ok. $48 \mathrm{~h}$ inkubacji. Po trzech dniach hodowli kolonie nabierają charakterystyczny wygląd "sadzonego jajka" [1-5,10,13-17,22,24-31]. 


\section{5. 2. Zagrożenie związane $z$ dżumą w przeszłości}

- pierwsze dobrze udokumentowane wzmianki na temat pandemii dżumy pochodzą z okresu panowania Cesarza Justyniana (VI w.). Choroba prawdopodobnie przybyła do Europy z Północnej Afryki i w ciągu półwiecza pochłonęła około $100 \mathrm{mln}$ ofiar

- w XIV w. dżuma pojawiła się ponownie w Europie (wielka pandemia „czarnej śmierci”).

- podczas trwania trzeciej pandemii, która rozpoczęła się w Chinach w 1855 r. odkryto czynnik etiologiczny tej choroby.

- w 1894 roku, niezależnie od siebie dwaj uczeni: Alexandre-Emile-John Yersin oraz Kitazato Shibasaburo wyizolowali pałeczkę dżumy - Yersinia pestis [1-5,10,13-17,22, 24-31].

\section{5. 3. Obecny stan epidemiologiczny}

- ostatnia większa epidemia w Mandżurii, w latach 1910-1911 (60 tys. zachorowań),

- w ostatnim pięćdziesięcioleciu na całym świecie jest notowanych ok. 1700 nowych przypadków zachorowań rocznie, z tego ok. 2-3 \% to dżuma płucna i pierwotna posocznica $[1-5,10,13-17,22,24-31]$.

\section{5. 4. Patogeneza i główne postacie dżumy}

- hamowanie agregacji płytek krwi (czynnik YopM) oraz fagocytozy granulocytów (YopH i E),

- zmiany w węzłach chłonnych,

- ciężkie zapalenie płuc,

- posocznica,

- patogen wywołuje kilka postaci klinicznych: dymieniczą, septyczną, płucną [1-5,10, 13-17,22,24-31].

\section{5. 5. Objawy i przebieg choroby}

- przeważnie człowiek ugryziony przez będącą wektorem pchłę choruje na postać dymieniczą,

- objawy: nagła wysoka gorączka, bole głowy oraz kończyn, a także wymiotami, dreszcze, kaszel z krwio-pluciem, sepsa,

- węzły chłonne pachwinowe i pachowe stają się silnie powiększone, osiągając niekiedy wielkość jaja,

- postać płucna jest łatwa do rozpylenia i charakteryzuje się wysoką zakaźnością i śmiertelnością (ok. $100 \%$ ),

- okres inkubacji wynosi około 2-3 dni,

- zachorowanie na dżumę wymaga zastosowania kwarantanny,

- istnieje ryzyko rozsiewania patogenów drogą kropelkową,

- w leczeniu stosuje się antybiotykoterapię oraz objawowe leczenie wspomagające [1-5,10,13-17,22,24-31].

\section{6. Zagrożenia wynikające z zakażenia cholerą (Vibrio cholerae)}

\section{6. 1. Charakterystyka patogenu}

Cholera jest to ostra zakaźna i zaraźliwa choroba jelit, wywołana przez bakterie przecinkowce cholery (Vibrio cholerae). 
Historia:

- Cholera od stuleci występowała stale w na subkontynencie indyjskim (tereny endemiczne).

- Od 1961 r. cholera rozszerzyła się z terenów Indonezji na prawie cały świat - rozpoczęła się 7 pandemia cholery, która trwa do dziś.

- W 1970 r. cholera weszła do Afryki, gdzie w ostatnich 2 latach jest najwięcej zachorowań. Do Ameryki Płd. Cholera dotarła w $1991 \mathrm{r}$.

- Do Europy cholera wtargnęła w 1970 r. W Europie każdego roku stwierdza się tzw. zachorowania za-wleczone - importowane, tzn. człowiek ulega zakażeniu poza krajem, w którym ulega zakażeniu.

- Epidemie szerzyły się w Polsce od 1831 r. do 1923 r. - później występowały jedynie pojedyncze ,zawleczone” zachorowania (w każdej chwili do Polski może przyjechać osoba w okresie wylęgania choroby) [1-5,10,13-17,22,24-31].

\section{6. 2. Drogi zakażenia}

- droga pokarmowa - wypicie wody skażonej odchodami osób chorych na cholerę lub nosicieli,

- rzadziej spożycie zakażonego pokarmu np. owoców morza.

Objawy:

- gwałtowne i częste biegunki (luźny stolec) oraz wymioty, co prowadzi do odwodnienia organizmu,

- szybkie oznaki odwodnienia - suchość skóry, zaostrzenie rysów twarzy, chrapliwy głos,

- obniżona ciepłota ciała, obniżone ciśnienie krwi, szybkie tętno (wstrząs choleryczny) [1-5,10,13-17,22,24-31].

\section{6. 3. Zapobieganie}

- kontrola źródeł wody,

- przestrzeganie zasad higieny - mycie rąk, owoców,

- picie wody świeżo przegotowanej lub mineralnej,

- izolacja osób chorych i nosicieli [1-5,10,13-17,22,24-31].

\section{7. Zagrożenia wynikające z zakażenia wirusem ospy i wirusowe gorączki krwotoczne}

\section{7. 1. Wirus ospy prawdziwej (Variola vera)}

- 1980 r. - WHO ogłosiła eradykację ospy prawdziwej,

- Wirusy ospy prawdziwej zdeponowano w dwóch referencyjnych laboratoriach WHO: w Moskwie i Atlancie, (ponowne pojawienie się tej choroby może być spowodowane jedynie celowym uwolnieniem wirusa lub jego ewentualnym odtworzeniem) $[1-5,11,13-17,22$, 24-31].

\section{7. 2. Czynnik etiologiczny}

- wirus ospy prawdziwej (Variola vera) - rodzina: Poxviridae, rodzaj: Orthopoxvirus,

- rozmiar: $320 \times 270 \mathrm{~nm}$,

- struktura: złożona, kapsyd składa się z systemu kanalików i może byd otoczony osłonką,

- kwas nukleinowy: dsDNA, koduje ponad 100 polipeptydów,

- replikacja: wyłącznie w cytoplazmie komórek,

- rezerwuar wirusa: człowiek [1-5,11,13-17,22,24-31]. 


\section{7. 3. Obecny stan epidemiologiczny}

Ostatni wypadek zachorowania na ospę miał miejsce w 1977 r. w Pakistanie. Obecnie chorobę uważa się za zwalczoną. Człowiek jest jedynym organizmem, w którym wirus może się rozwijać. Teoretycznie istnieje możliwość odtworzenia wirusa (zwłaszcza rekombinowego np. z wirusa ospy małpiej). Rozważane jest przywrócenie szczepień (w Polsce obowiązkowe do 1980 r.). W dawnych planach militarnych była rozważana dla wywołania tzw. „last epidemy" - ataku biologicznego po ataku nuklearnym [1-5,11,13-17,22,24-32].

\section{7. 3. Patogeneza}

Zakażenie głownie drogą kropelkową: wirusy są bezwzględnym pasożytem wewnątrzkomórkowym - namnażając się, powodują ich rozpad (zwłaszcza skory, błon śluzowych, w węzłach chłonnych) [1-5,10,13-17,22,24-31].

\section{7. 4. Wirus ospy prawdziwej jako broń biologiczna}

- duża zakaźność: ok. 100 cząstek wirusa wchłoniętych z powietrza powoduje chorobę i długi okres wylęgania,

- rosnąca podatność populacji (u nieszczepionych osób podatność wynosi 100\%),

- wysoka zaraźliwość epidemiczna w postaci kropelkowej (każdy chory stanowi źródło zakażenia 10-20 osób nieszczepionych), poza tym zakaźne są także przedmioty i pościel,

- wysokie prawdopodobieństwo wymknięcia się epidemii spod kontroli,

- wysoka śmiertelność (ok.30\%populacjinieszczepionej),

- stabilność wirusa w postaci aerozolu,

- budzący przerażenie wygląd chorych,

- trudność w uzyskaniu/pozyskaniu wirusa [1-5,10,13-17,22,24-31].

\section{7. 5. Postacie choroby}

- variola major (śmiertelność 30 \%),

- variolamajor - postać krwotoczna (śmiertelność dok. $100 \%$ ),

- variolamajor - postać złośliwa (śmiertelność powyżej $50 \%$ ),

- variola minor (śmiertelność ok. $1 \%$ ) [1-5,10,13-17,22,24-31].

\section{7. 6. Objawy i przebieg choroby}

- brak objawów (10 - 12 dni),

- gorączka, zmęczenie, bole głowy, pleców, brzucha (3-4 dni),

- postępująca wysypka: plamista, grudkowa, pęcherzykowa, krostkowa (8-9 dni),

- tworzenie strupów, dołkowate blizny,

- zgon następuje zwykle w drugim tygodniu choroby,

- pospolite pozostałości ospy: tzw. ,dzioby” ospowe (blizny i zwłóknienia w tkance podskórnej), blizny wokół ust, zniekształcenia powiek (niedomykanie, wywinięcie) $[1-5,10,13-17,22,24-31]$. 


\section{8. Zagrożenia wynikające z zakażenia wirusowymi gorączkami krwotocznymi}

\section{8. 1. Charakterystyka patogenu}

Grupa wirusowych schorzeń odzwierzęcych, przenoszonych najczęściej przez stawonogi od chorych nosicieli (ludzi i zwierząt) albo w postaci aerozolu lub drogą kontaktową (kategoria zagrożenia A), charakteryzujących się uszkodzeniem naczyń krwionośnych (wybroczyny, krwawienia) i zwykle dużą śmiertelnością przy epidemiach (5$90 \%$ ). Wywoływane są przez nie spokrewnione ze sobą bezpośrednio wirusy RNA [1$5,10,13-17,22,24-31]$.

\section{8. 2. Systematyka wirusów wywołujących gorączki krwotoczne}

- RODZINA FILOVIRIDAE (WIRUS EBOLA, WIRUS MARBURG),

- RODZINA BUNYAVIRIDAE (WIRUS HANTA, WIRUS GORĄCZKI DOLINY RIFT, WIRUS GORĄCZKI KRWOTOCZNEJ KONGO),

- RODZINA ARENAVIRIDAE (WIRUS GORĄCZKI LASSA, WIRUS JUNIN, WIRUS MACHUPO, WIRUS GUANTARIO, WIRUS SABIA),

- RODZINA FLAVIVIRIDAE (WIRUS DENGUE, WIRUS ŻÓLTEJ GORĄCZKI) [1-5,10,13-17,22,24-31].

\section{8. 3. Wirusowe gorączki krwotoczne}

1. FILOVIRIDAE

- WIRUS MARBURG - CHOROBA MARBURSKA

- WIRUS EBOLA - ZAKAŻENIE WIRUSEM EBOLA

2. BUNYAVIRIDAE

- WIRUS HANTA - HANTAWIRUSOWY ZESPOŁ PŁUCNY I ZESPOŁ NERKOWY

- PHLEBOVIRUS - GORĄCZKA DOLINY RIFT

- NAIROVIRUS - KRYMSKO-KONGIJSKA GORĄCZKA KRWOTOCZNA

3. ARENAVIRIDAE

- ARENAVIRUS - GORACZZKA LASSA

- WIRUS MACHUPO - BOLIWIJSKA GORACZZKA KRWOTOCZNA

- WIRUS JUNIN - ARGENTYOSKA GORĄCZKA KRWOTOCZNA

- WIRUS GUANTARIO - GORĄCZKA WENEZUELSKA

- WIRUS SABIA - GORĄCZKA BRAZYLIJSKA

4. FILOVIRIDAE

- FLAVIVIRUS - ŻÓŁTA GORĄCZKA, GORĄCZKA KRWOTOCZNA DENGA [1-5,10,13-17,22,24-31].

\section{9. Rycyna jako broń biologiczna}

W 1978 roku, bułgarski dysydent pracujący dla BBC, Georgij Markow, czekał na autobus na stacji Waterloo Bridge w Londynie. Nagle został potrącony przez mężczyznę z parasolem. Wieczorem miał wysoką gorączkę. Po czterech dniach zmarł. Na zlecenie żony przeprowadzono autopsję. $Z$ ciała dziennikarza wydobyto drobną kulę (1,52 $\mathrm{mm}$ średnicy). $\mathrm{Na}$ wieść o śmierci Markowa, pracujący dla Radia Wolna Eu-ropa, Władimir Kostow (również przeciwnik ówczesnego reżimu Żiwkowa), przypomniał sobie, że kilka dni wcześniej czekając na stacji metra w Paryżu również został ukłuty parasolką. Prześwietlenie 
wykazało obecność drobnego naboju. Obydwu ataków dokonały bułgarskie służby specjalne na zlecenie rządu. "Parasol" dostarczyło "zaprzyjaźnione" KGB. W odzyskanym naboju zachował się czynnik, który został zidentyfikowany jako rycyna [1-5,10,13-17,22,24-31].

\subsection{Pochodzenie}

Rycyna jest substancją pochodzenia roślinnego. Można ją uzyskać z odpadów z nasion rącznika pospolitego (Ricinus communis, rodzina Euphorbiaceae), z których wytłacza się olej rycynowy (zawartość w nasionach wynosi 1 do $5 \%$ ). Sam olej nie zawiera rycyny $[1-5,10,13-$ 17,22,24-31].

\subsection{Mechanizm działania}

Dwa łańcuchy białkowe które są wchłaniane do komórki droga endocytozy ni blokują wewnątrzkomórkową syntezę białek w aparacie Golgiego. Jest silnie toksyczna, połknięcie (i pogryzienie) kilku do kilkunastu nasion rącznika jest dla człowieka śmiertelne, pomimo, że rycyna stosunkowo słabo absorbowana jest przez śluzówkę jelita [1-5,10,13-17,22,24-31].

\subsection{Objawy zatrucia rycyną}

Pojawiają się w ciągu kilku godzin od chwili ekspozycji. Towarzyszy im gorączka i martwica tkanek. Zatrucie pokarmowe u ludzi kończy się śmiercią w 1,9\% przypadków. Najczęściej występujące symptomy to: nagłe wymioty, nudności, bole brzucha, biegunka, krwawienie, bezmocz, rozszerzenie źrenic. Zatrucia drogą wziewną powoduje niewydolność oddechowa oraz obrzęk płuc [1-5,10,13-17,22,24-31].

\section{10. Salmonelloza (Salmonella sp.) jako broń biologiczna}

- Celowe zakażenie produktów żywnościowych na skalę masową pałeczkami Salmonella sp. może być wywołane przez terrorystów i spowodować masowe zachorowania obciążające znacznie służbę zdrowia i powodujące straty ekonomiczne oraz psychozę społeczną.

- Takie przypadki działań terrorystycznych, choć w niewielkiej skali, są znane [15,10,13-17,22,24-31].

\section{11. Chlamydioza (Chlamydia sp.) jako broń biologiczna}

- Chlamydia psittaci może być użyta w formie aerozolowej jako broń biologiczna.

- Powoduje ostrą postać zapalenia płuc oraz zakażenie uogólnione z objawami toksemii i śmiertelnością nawet do $20 \%$.

- W przypadkach masowych zachorowań u osób, które nie miały kontaktu z papugami, rozpoznanie tej choroby może być bardzo trudne, ale ustalenie prawidłowego rozpoznania $\mathrm{w}$ tych przypadkach jest praktycznie jednoznaczne $\mathrm{z}$ ujawnieniem ataku bioterrorystycznego [1-5,11,13-17,19,22,24-32].

\section{12. Gorączka Q (Coxiella burnetii) jako broń biologiczna}

- Cechuje się dużą zaraźliwością przy zakażeniu drogą aerozolową (dawka zakażająca 1-10 mikroorganizmów) i jest w swojej formie bardzo oporna na warunki środowiskowe. 
- Według symulacji ekspertów WHO rozproszenie $50 \mathrm{~kg}$ tego patogenu na wysokości 2 $\mathrm{km}$ nad terenem zamieszkałym przez 500000 ludzi spowoduje zachorowania 125000 osób i 150 zgonów.

- Mimo tak niskiej śmiertelności jest to choroba o ciężkim przebiegu i w przypadku zachorowań masowych powoduje niewydolność systemu służby zdrowia, znaczne szkody ekonomiczne i oczekiwany przez terrorystów efekt psychologiczny $[1-5,11,13$ 17,22,24-32].

\section{13. Escherichia coli 0157:H7 jako broń biologiczna}

- Enterohemolityczny szczep E. coli wytwarzający werotoksynę (werocytotoksynę).

- Powoduje ona biegunki i powikłania schorzeń nadnerczy oraz groźny zespół hemolityczno-mocznicowy.

- Główną przyczyną infekcji bakterią jest spożycie wołowiny niepoddanej obróbce termicznej [1-5,9,10,13-17,23,24-31].

\section{WNIOSKI}

1. Broń biologiczna jest jednym z najważniejszych zagrożeń nie tylko dla sił zbrojnych, lecz również dla ludności cywilnej we współczesnym świecie.

2. Ataki terrorystyczne z użyciem broni biologicznej mogą nastąpić poprzez rozpylenie aerozolu, skażenie żywności i ujęć wody oraz metodami niekonwencjonalnymi takimi jak - np.: w przesyłkach, poprzez skażenie przedmiotów użytku codziennego, środków komunikacyjnych, itp.).

3. Wiedza na temat bioterroryzmu wśród społeczeństwa nie tylko w Polsce, ale również na świecie jest niewielka. Bardzo ważnym elementem zapobiegania i skutecznego przeciwdziałania skutkom biologicznych środków rażenia jest posiadanie sprawnego i zintegrowanego systemu nadzoru epidemiologicznego oraz sieci wyspecjalizowanych akredytowanych laboratoriów mikrobiologicznych zdolnych do szybkiej diagnostyki.

4. Bardzo ważną kwestią jest odpowiednie wyszkolenie i wyposażenie personelu służb ratowniczych i służby zdrowia działających według opracowanych procedur przez służby odpowiedzialne za bezpieczeństwo.

\section{References}

[1] Aleksandrowicz T. R., Nowy terroryzm, [w:] Współczesne zagrożenia terroryzmem oraz metody działań antyterrorystycznych, red. J. Szafrański, Szczytno 2007.

[2] Altermatt U., Sarajewo przestrzega. Etnonacjonalizm w Europie, Znak, Kraków 1998.

[3] Archick K., Gallis P., Europe and Counterterrorism, Nova Science Publishers, New York 2003.

[4] Barcz J., Prawo Unii Europejskiej - zagadnienia systemowe, Prawo i Praktyka Gospodarcza, Warszawa 2002.

[5] Barcz J., Traktat z Nicei-zagadnienia prawne i instytucjonalne, Prawo i Praktyka Gospodarcza, Warszawa 2003 r. 
[6] Beck U., Władza i przeciwwładza w epoce globalnej. Nowa ekonomia polityki światowej, Wyd. Naukowe Scholar, Warszawa 2005.

[7] Białek Tomasz, Terroryzm manipulacja strachem, Studio EMKA, Warszawa 2005.

[8] Bieleń S., Prawo w stosunkach międzynarodowych. Wybór dokumentów, Warszawa 1988.

[9] Bożek M., Troszyński M. (red.), Europa - kontynent ryzyka? Społeczne, polityczne i normatywne uwarunkowania bezpieczeństwa w Europie, Wyd. AON, Warszawa 2007.

[10] Chomiczewski K., Kocik J., Szkoda M. T., Bioterroryzm. Zasady postepowania lekarskiego, Warszawa, Wydawnictwo Lekarskie PZWL, 2002.

[11] Daniszewski P., International Letters of Social and Humanistic Sciences 1 (2013) 28-34.

[12] Flemming M., Terroryzm polityczny w międzynarodowym prawodawstwie, Wojskowy Przegląd Prawniczy nr 1, 1996.

[13] Jenkins B. M., International Terrorism. A New Mode of Conflict. California Seminar on Arms Control and Foreign Policy, Los Angeles 1975.

[14] Kiełtyka A., Amerykańska ustawa antyterrorystyczna z 2001r. (The USA Patriot Act of 2001), Prokurator 2-3 (2005) 22-23.

[15] Koziej S., Między piektem a rajem: szare bezpieczeństwo na progu XXI wieku, Wyd. Adam Marszałek, Toruń 2006.

[16] Kumaniecki K., Stownik łacińsko-polski, Państwowe Wydawnictwo Naukowe, Warszawa 1982.

[17] Kunikowski J., Turek A. (red.), Bezpieczeństwo i dyplomacja. Słownik terminów, Wyd. Pedagogium, Warszawa 2008.

[18] Laqueur W., Reflections on Terrorism, - Foreign Affairs No 1, Vol. 65, 1986.

[19] Liedel K., Piasecka P., Wspótpraca międzynarodowa w zwalczaniu terroryzmu, Oficyna Wydawnicza Adam, Warszawa 2004.

[20] Machowski A., Zagrożenia bioterroryzmem. Dydaktyczno - prewencyjne aspekty zarządzania bezpieczeństwem społecznym, Mysłowice 2008.

[21] Madej M., Użycie siły przez podmioty pozapaństwowe jako „,nowy problem studiów strategicznych, [w:] Stosunki międzynarodowe w XXI wieku. Księga jubileuszowa z okazji 30-lecia Instytutu Stosunków Międzynarodowych Uniwersytetu Warszawskiego, red. E. Haliżak, R. Kuźmiar, G. Michałowska, S. Parzymies, J. Simonides, R. Zięba, Warszawa 2006,

[22] Madej M., Zagrożenia asymetryczne bezpieczeństwa państw obszaru transatlantyckiego, Polski Instytut Spraw Międzynarodowych, Warszawa 2007,

[23] Malec M., Percepcja bezpieczeństwa: definicje, wymiary, paradygmaty, Wyd. MON, Warszawa 2006.

[24] Moss R., Urban Guerilla Warfare, Adelphi Paper, No 79, London 1971,

[25] Muszyński J. (red.), Terroryzm polityczny, Warszawa 1981, 
[26] Oakley R., International Terrorism, „Foreign Affairs, America and the World No 3, Vol. 65, 1987.

[27] Pikulski S., Prawne środki zwalczania terroryzmu, Olsztyn 2000.

[28] Szlachter D., Walka z terroryzmem w Unii Europejskiej. Nowy impuls, Toruń 2006.

[29] Zieliński K., Brocki M., Janiak M., Wiśniewski A., Patologia obrażeń i schorzeń wywołanych wspótczesna bronia $w$ działaniach wojennych $i$ terrorystycznych, Wydawnictwo MON, Warszawa, 2010.

[30] Żuber M.(red.), Katastrofy naturalne i cywilizacyjne. Zagrożenia cywilizacyjne początku XXI wieku, WSOWL, Wrocław 2007.

[31] Protokół Kartageński o Bezpieczeństwie Biologicznym do Konwencji o Różnorodności Biologicznej. Dz..U. z 2004 r., Nr 216, poz. 2201.

[32] Heisbourg F., Wojny, Prognozy XXI wieku, Warszawa: Prószyński i S-ka, 1998, s. 55. 